\title{
Tinjauan Hukum Persaingan Usaha dalam Praktek Persekongkolan Tender (Studi Putusan Nomor:04/KPPU-L/2018)
}

\author{
Rendi Ardiansyah*, Margo Hadi Pura \\ Fakultas Hukum Universitas Singaperbangsa Karawang \\ Jl. Hs. Ronggo Waluyo, Puseurjaya, Kec. Telukjambe Timur, Kabupaten Karawang, Jawa Barat 41361 \\ *Correspondence Email: Rendi.Ardiansyah26@gmail.com; Oficiumnobile@gmail.com
}

\begin{abstract}
Abstrak. Keberadaan Undang-Undang Nomor 5 Tahun 1999 diharapkan bisa memberantas praktik monopoli dan persaingan usaha tidak sehat dalam dunia usaha yang terus berkembang dengan persaingan yang semakin ketat. Namun, hingga saat ini masih banyak terjadi praktik usaha yang tidak sehat karena persaingan yang semakin kompleks serta tuntutan untuk mendapatkan keuntungan yang semaksimal mungkin dari kegiatan usahanya, salah satunya berkaitan dengan kegiatan persekongkolan tender yang dilakukan dalam pengadaan barang maupun jasa dilingkungan pemerintahan. Di antaranya praktik persekongkolan tender Putusan Komisi Pengawas Persaingan Usaha Nomor 04/KPPU-L/2018. Dalam penulisan artikel ini menggunakan metode penelitian yuridis normatif di mana penelitian serta observasi yang dilakukan secara kepustakaan dengan menekankan pada kaidah hukum yang berlaku. Penulisan artikel ini bertujuan untuk mengetahui persekongkolan tender dalam pandangan hukum persaingan usaha yang pada hakikatnya dilarang karena akan mencegah pelaku usaha lain untuk ikut bersaing dalam menawarkan harga pada lelang. Selain itu, artikel ini membahas mengenai pemenuhan rumusan unsur-unsur dalam praktik persekongkolan tender pada perkara a quo. Persekongkolan tender secara khusus diatur dalam Pasal 22 Undang-Undang Nomor 5 Tahun 1999 yang kemudian dilengkapi melalui diterbitkannya Pedoman Pasal 22 oleh KPPU. Bahwa pada pokoknya tindakan para Terlapor dalam pelaksanaan tender a quo merupakan suatu praktik persekongkolan tender karena telah memenuhi segala unsur yang dimaksud dalam pasal 22 Undang-Undang Nomor 5 Tahun 1999 hingga berakibat menerima penjatuhan sanksi administratif yang diberikan oleh KPPU sebagai bentuk penegakan hukum.
\end{abstract}

Kata Kunci: Tinjauan Hukum, Persaingan Usaha, Persekongkolan Tender

\begin{abstract}
The existence of Law Number 5 Year 1999 is expected to prevent monopolistic practices and unfair business competition in a business world that continues to develop with increasingly fierce competition. However, until now there are still many unfair effort practices because increasingly complex competition and demands for profusely profit, one of which is related to tender conspiracy activities carried out in the procurement of goods and services within the government. Between them are the practice of conspiracy to tender for the Decision of the Business Competition Supervisory Commission Number 04/ KPPU-L/2018. In writing this article using a normative juridical research method in which research and observations are carried out in a library by emphasizing the applicable legal principles. The purpose of writing this article is to find out tender conspiracy in view of business competition law, which is essentially prohibited because it will prevent other business actors from competing in offering prices at the auction. In addition, this article discusses the fulfillment of the formulaic elements in the practice of tender conspiracy in the a quo case. Tender conspiracy is specifically regulated in Article 22 of Law Number 5 Year 1999 which is then complemented by the guidelines issuance of Article 22 by KPPU. Whereas in essence the actions of the Reported Parties in the implementation of the a quo tender constituted a tender conspiracy practice because they had complied with all the elements referred to in Article 22 of Law Number 5 Year 1999 resulting in receiving administrative sanctions imposed by KPPU as a form of law enforcement.
\end{abstract}

Keywords: Legal Review, Business Competition, Tender Conspiracy

\section{PENDAHULUAN}

Indonesia sebagai negara hukum telah menggariskan tujuan Pembangunan Perekonomian guna menciptakan kehidupan dalam masyarakat yang adil, makmur, sentosa, serta sejahtera sebagaimana cita dan amanat UndangUndang Dasar 1945 dan Pancasila demi terwujudnya pembangunan nasional yang merata secara keseluruhan bagi rakyat Indonesia. Sebagai usaha untuk mengimplementasikan tujuan tersebut maka dibuatlah Undang-Undang Nomor 5 Tahun 1999 Tentang Larangan Praktik Monopoli dan Persaingan Usaha. Karena dunia usaha merupakan salah satu faktor yang dapat mempengaruhi pembangunan nasional.

Kelahiran Undang-Undang Nomor 5 Tahun 1999 Tentang Larangan Praktik Monopoli dan Persaingan Usaha Tidak Sehat yang disahkan pada tanggal 5 Maret 1999 bertujuan untuk mewujudkan keadaan kondusif bagi dunia serta dapat mendorong Indonesia menuju kancah perekonomian dunia, karena persaingan merupakan bagian dari suatu unsur yang sangat mendasar dalam perekonomian dan merupakan syarat mutlak guna terciptanya persaingan yang sehat.

Dalam menghadapi situasi demikian, peran hukum persaingan usaha sangat diperlukan guna mencegah persaingan usaha tidak sehat sebagai upaya menjaga keseimbangan ekonomi pasar. Setiap pelaku usaha harus mempunyai kesempatan yang sama dalam pasar. Maka dari itu, dengan adanya hukum yang mengatur persaingan 
usaha diharapkan dapat menjamin hal tersebut. Sehingga, dapat menciptakan atmosfir persaingan usaha yang kompetitif sesuai dengan mekanisme pasar serta dapat menghidari terjadinya sentralisasi ekonomi pada individu maupun kelompok tertentu.

Keberadaan Undang-Undang Nomor 5 Tahun1999 diharapkan memberikan jaminan serta kepastian hukum guna mencegah praktik-praktik monopoli dan persaingan usaha tidak sehat, sehingga diharapkan dapat menciptakan keefektifan dan keefisienan dalam melaksanakan aktivitas usahanya guna terciptanya kesejahteraan bagi rakyat dan pembangunan nasional. ${ }^{1}$ Sehingga diharapkan diantara para pelaku usaha yang bersaing dalam pasar terdapat kesempatan sepadan untuk ikut bersaing dalam pasar. Karena mekanisme pasar berjalan berdasarkan prinsip keseimbangan yang tercipta berdasarkan kekuatan penawaran oleh pelaku usaha dan permintaan dari konsumen. ${ }^{2}$ Walaupun, pada dasarnya usaha untuk memperoleh profit yang semaksimal mungkin dalam dunia usaha merupakan perilaku yang wajar yang harus dilakukan oleh para Pelaku Usaha. ${ }^{3}$ Akan tetapi, usaha untuk mendapatkan keuntungan sebesar-besarnya tersebut harus dilakukan dengan cara yang bersih tanpa melanggar peraturan yang ada dan tidak menimbulkan persaingan usaha tidak sehat.

Namun dalam kenyataannya, praktik persaingan usaha tidak sehat tidak bisa dihindari. Walaupun praktik usaha yang seperti itu telah dilarang dalam Undang-Undang yang berlaku. Para pelaku usaha khususnya, melakukan berbagai cara demi meraup profit yang semaksimal mungkin. Dalam pasar, para oknum pelaku usaha berusaha untuk menciptakan persaingan semu seolah-olah telah terjadi persaingan usaha yang sehat.

Salah satu di antara kegiatan yang dilarang adalah mengenai persekongkolan tender yang telah diatur dalam pasal 22 Undang-Undang Nomor 5 Tahun 1999 Tentang Larangan Praktik Monopoli dan Persaingan Usaha Tidak Sehat. Persekongkolan dalam tender biasanya berkaitan dengan pengadaan barang dan/atau jasa yang dilakukan oleh pemerintah (Government Procurement). Akan tetapi, ruang lingkup pada Undang-Undang Nomor 5 Tahun 1999 dapat tidak hanya mencakup kegiatan yang dilaksanakan pemerintah saja melainkan juga meliputi kegiatan pada sektor swasta. ${ }^{4}$ Pada pokoknya, persekongkolan tender yakni suatu bentuk tindakan yang dilakukan, baik oleh pihak penyedia barang/jasa maupun pengguna barang/jasa untuk mengatur kemudian menetapkan pemenang tender. ${ }^{5}$

Persekongkolan tender telah menjadi permasalahan persaingan usaha yang masih sering dapat dijumpai di Indonesia terutama dalam proses pengadaan barang dan/atau jasa dilingkungan pemerintah. Karena, berdasarkan laporan tahunan serta direktori putusan yang telah dibuat oleh Komisi Pengawas Persaingan Usaha sering sekali menginvestigasi dan memutus kasus persekongkolan tender. Dalam proses pengadaan barang dan/atau jasa pemerintah para pihak yang terlibat dalam tender melakukan berbagai cara untuk mengatur pemenang tender bahkan tidak hanya para pelaku usaha tetapi juga panitia pelaksana atau penyelenggara tender yang berasal dari pemerintah pun turut bersekongkol. Hal tersebut jelas sangat bertententangan dengan peraturan yang telah ada.

Konspirasi atau persekongkolan pada proses penawaran umum merupakan bentuk kesepakatan kerja sama di antara para partisipan tender yang semestinya saling bersaing secara sehat sesuai dengan mekanisme yang diatur dalam peraturan yang berlaku namun hal tersebut tidak dilakukan karena tujuan yang ingin dicapainya adalah kemenangan salah satu pihak yang telah direncanakan. Kesepakatan itu diadakan oleh satu ataupun lebih peserta tender dengan menyetujui tidak menyerahkan penawaran, atau melalui kesepakatan mengajukan harga tender lebih rendah guna merekayasa untuk memenangkan peserta tender dengan harga yang lebih tinggi. ${ }^{6}$

Komisi Pengawas Persaingan Usaha sebagai instansi negara yang indepeden yang berwenang melakukan pengawasan terhadap persaingan usaha di Indonesia tentunya memilki tugas yang berat agar dapat menjamin proses tender berlangsung secara sehat sesuai dengan aturan yang ada agar dapat menghindarkan terjadinya praktek persekongkolan. Hal tersebut sulit diwujudkan jika tidak didukung oleh infrastruktur yang memadai dan kesediaan pihak lain yang terkait untuk turut berkoordinasi untuk mencegah praktek persekongkolan tender. Hukuman-hukuman yang diberikan oleh Komisi Pengawas Persaingan Usaha masih belum memberikan efek jera bagi para pelaku usaha dan pengawai pemerintahan yang terkait dan turut serta dalam persekongkolan tender yang merupakan kegiatan yang dilarang oleh Undang-Undang dalam pengadaan suatu barang maupun jasa, hal tersebut dapat terlihat dengan terus

${ }^{1}$ Asmah, "Penerapan Sanksi Denda Terhadap Kasus Persekongkolan Tender Jalan Nasional” (2019, Agustus), Jurnal YudisialVol. 12, No. 2, (Agustus 2019): 201.

2 Johnny Ibrahim, Hukum Persaingan Usaha: Filosofi, Teori, dan Implikasi Penerapannya di Indonesia, (Malang: : Bayumedia Publishing, 2007), hlm. 129.

3 Wisny, "Penerapan Sanksi Administratif Oleh Komisi Pengawas Persaingan Usaha (KPPU) Terhadap Pelaku Usaha Yang Melakukan Persekongkolan Tender”, Pakuan Law ReviewVol 1, No. 2, (Juli-Desember 2015): 362.

${ }^{4}$ Rocky Marbun, Persekongkolan Tender Barang/Jasa, (Yogyakarta: Pustaka Yustisia, 2010), hlm 24.

5 Alya Anindita Maheswari, "Batasan, Wewenang dan Keterlibatan KPPU Dalam Kasus Persekongkolan Tender Menurut Hukum Persaingan Usaha”, Jurist-Diction Vol 3, No. 5, (September 2020) : 1584.

${ }^{6}$ Dewi Nawang Wulan et al., "Persekongkolan Tender Dalam Persaingan Usaha Menurut UU No. 5 Tahun 1999 Tentang Larangan Praktik Monopoli Dan Persaingan Usaha Tidak Sehat”, MIMBAR YUSTITIAVol 3, No. 3, (Desember 2019 ): 107. 
meningkatnya laporan yang diterima serta investigasi oleh Komisi Pengawas Persaingan Usaha terkait dengan dugaan persekongkolan tender di sektor pemerintah. ${ }^{7}$

Persekongkolan tender dalam lelang preservasi rekonstruksi jalan dan pemeliharaan rutin jembatan Palangka Raya-Bagugus-Bukit Batu Kalimantan Tengah yang dilakukan oleh Kelompok Kerja (Pokja) Pengadaan Barang/Jasa satuan kerja pelaksanaan Jalan Nasional Wilayah III (Terlapor I) dengan 2 pelaku usaha lain yaitu PT. Jaya Wijaya Coperation (Terlapor II) dan PT. Margo Umega (Terlapor III). Ketiganya merupakan Terlapor dalam kasus persekongkolan tersebut. Adapun yang menjadi Objek Perkara tersebut adalah Paket Preservasi Rekonstruksi Jalan dan Pemeliharaan Rutin Jembatan Palangka Raya-Bagugus-Bukit Batu Kalimantan Tengah dengan Nilai HPS sebesar Rp. 34.131.220.000,00 (tiga puluh empat miliar seratus tiga puluh satu juta dua ratus dua puluh ribu rupiah) yang bersumber dari APBN Kementerian Pekerjaan Umum dan Perumahan Rakyat Tahun Anggaran 2017. Berdasarkan keputusan Komisi Pengawas Persaingan Usaha Nomor 04/KPPU-L/2018 ketiga terlapor telah terbukti secara sah dan meyakinkan melanggar pasal 22 Undang-Undang Nomor 5 Tahun 1999 Tentang Larangan Praktek Monopoli dan Persaingan Usaha Tidak Sehat. Bahkan para terlapor dalam perkara a quo juga terlibat dalam beberapa perkara persekongkolan tender paket lelang yang lain. Beberapa terlapor dalam perkara a quo juga diputus bersalah telah melakukan persekongkolan tender. berikut:

Berdasarkan hal tersebut, yang menjadi rumusan dalam penulisan artikel ilmiah ini diantaranya adalah sebagai

1. Bagaimana Persekongkolan Tender dalam pandangan Hukum Persaingan Usaha?

2. Bagaimana pemenuhan unsur-unsur persekongkolan tender pada Putusan Komisi Pengawas Persaingan Usaha Perkara Nomor 04/KPPU-L/2018?

State of the art diambil dari penelusuran beberapa contoh penelitian terdahulu yang digunakan sebagai panduan dan acuan dalam melakukan penelitian ini, yaitu berupa jurnal antara lain:

1. Artikel yang ditulis oleh Asmah yang berjudul "Penerapan Sanksi Denda Terhadap Kasus Persekongkolan Tender Jalan Nasional". Pada jurnal Yudisial Volume 12, No.2 pada 2019, yang meneliti mengenai penjatuhan sanksi denda terhadap kasus persekongkolan Tender Jalan Nasional.

Pembaharuan dalam penelitian ini adalah mencoba untuk melakukan pembahasan mengenai bagaimana pandagan Hukum persaingan usaha terhadap praktek persekongkolan tender khususnya pada kasus tender lelang preservasi rekonstruksi jalan dan pemeliharaan rutin jembatan Palangka Raya-Bagugus-Bukit Batu Kalimantan Tengah. Mengingat begitu pentingnya persaingan usaha yang sehat dan adil terhadap pembangunan dan kesejahteraan masyarakat maka dirasa perlu untuk membuat artikel ini.

\section{METODE}

Dalam penyusunan serta penulisan artikel ini menggunakan metode penelitian Yuridis Normatif. Artikel ini menggunakan peraturan dan ketentuan tertulis sehingga penelitian dan observasi yang dilakukan sangat erat kaitan hubungannya pada kepustakaan karena membutuhkan data-data yang bersifat sekunder. Penelitian ini dikaji dan disusun dari berbagai aspek seperti aspek filosofi, aspek teori, struktur/komposisi, perbandingan, penjelasan umum dan penjelasan tiap pasal, serta formalitas dan kekuatan mengikat undang-undang sehingga dalam penelitian ini mempunyai cakupan yang luas. Metode penelitian yuridis normatif atau hukum normatif yakni sebuah bentuk penelitian terhadap konsep hukum dalam arti personal kepustakaan, hal ini mengakibatkan penelitian normatif cenderung dituntut pada aspek kompleksifitas pustaka sebagai sumber informasi yang valid untuk digunakan. ${ }^{8}$

\section{HASIL DAN PEMBAHASAN \\ Persekongkolan Tender dalam Pandangan Hukum Persaingan Usaha}

Pada prinsipnya UU persaingan usaha merupakan arah dan juga batasan dalam pelaksaan persaingan usaha baik sebagai petujuk mengenai bagaimana seharusnya bertindak dan juga batasan mengenai hal-hal yang tidak boleh dilakukan. UU tersebut sejak awal dikonsepkan untuk mencegah terjadinya ekspolitasi pasar dan konsumen.

Persaingan usaha dalam praktiknya tidaklah berjalan sebagaimana mestinya, seringkali dengan dalih mendapatkan keuntungan yang sebesar-besarnya seseorang dengan sadar melakukan segala cara baik dengan tidak jujur atau bahkan melawan hukum. Salah satu bentuk tindakan tidak jujur dan melawan hukum dalam persaingan usaha adalah persekongkolan tender.

Persekongkolan sendiri didefinisikan sebagai kerja sama yang melibatkan dua atau lebih pelaku usaha dan atau panitia pemberi kerja, yang bersama-sama melakukan kesepakatan untuk melakukan tindakan melawan hukum yang

\footnotetext{
${ }^{7}$ Rocky Marbun, Op. Cit, hlm 63-64.

${ }^{8}$ Susanti, dkk, Penelitian Hukum Legal Research, (Yogyakarta: Sinar Grafika, 2017), hlm. 114.
} 
pembuktiannya tidak tertuju terhadap ada atau tidaknya perjanjian tetapi melihat keadaan secara langsung. ${ }^{9}$ Sedangkan menurut Pasal 1 huruf h UU 5/1999 mengartikan persekongkolan atau konspirasi sebagai suatu bentuk kerja sama yang dilakukan oleh pelaku usaha dengan pelaku usaha lain dengan maksud untuk menguasai pasar bersangkutan bagi kepentingan pelaku usaha yang bersengkongkol.

Tender menurut penjelasan Pasal 22 diartikan sebagai tawaran mengajukan harga untuk membrorong suatu pekerjaan, untuk mengadakan barang-barang, atau untuk menyediakan jasa. Sehingga dapat dijelaskan bahwa tender adalah suatu kegiatan dalam bentuk penawaran terhadap pemborongan pekerjaan atau pengadaan barang/jasa yang dilakukan oleh panitia tender dan pelaku usaha/jasa, yang dalam menentukan pemenangnya berdasarkan harga penawaran terendah dan memenuhi kualitas dan mutu yang telah ditetapkan.

Proses tender sendiri dirancang sebagai upaya untuk mendapatkan penawaran harga termurah dengan kualitas yang telah ditetapkan. Dengan adanya proses tender setiap pelaku usaha memiliki akses dan kesempatan yang sama untuk dapat mengikuti penawaran secara adil dan terbuka. Proses tender yang kompetitif akan medorong pelaku usaha untuk dapat mengadakan barang/jasa yang berkualitas dan biaya yang lebih rendah namun hal tersebut tidak akan terwujud apabila didalamnya terjadi persekongkolan.

Larangan mengenai praktek persekongkolan tender dapat ditemui dalam Pasal 22 dan Pasal 23 UU 5/1999 yang menyatakan bahwa:

\section{Pasal 22}

"Pelaku usaha dilarang bersekongkol dengan pihak lain untuk mengatur dan atau menentukan pemenang tender sehingga dapat mengakibatkan terjadinya persaingan usaha tidak sehat."

\section{Pasal 23}

"Pelaku usaha dilarang bersekongkol dengan pihak lain untuk mendapatkan informasi kegiatan usaha pesaingnya yang diklasifikasikan sebagai rahasia perusahaan sehingga dapat mengakibatkan terjadinya persaingan usaha tidak sehat"

Berdasarkan ketentuan diatas dapat diuraikan bahwa persekongkolan yang dilarang sebagai berikut: ${ }^{10}$

1. Melakukan pengaturan dan atau penentuan pemenang tender tanpa melalui proses yang telah ditetapkan.

2. Bersekongkol mendapatkan informasi kegiatan perusahaan lain yang sebenarnya informasi tersebut seharusnya dirahasiakan.

3. Bersekongkol mendapatkan informasi perusahaan lain yang sebenarnya informasi tersebut seharusnya dirahasiakan.

Sebagaimana ketentuan pasal 22 Undang-Undang Nomor 5 Tahun 1999 yang telah diubah dalam putusan Mahkamah Konstitusi Nomor: 85/PUU-XIV/2016 bahwa:

"Pelaku usaha dilarang bersekongkol dengan pelaku usaha lain dan/atau pihak yang terkait dengan pelaku usaha lain untuk mengatur dan/atau menentukan pemenang tender sehingga dapat mengakibatkan terjadinya persaingan usaha tidak sehat." Apabila ketentuan Pasal 22 apabila diuraikan maka dapat ditemukan unsur-unsur dalam persekongkolan tender, di mana unsur tersebut sebagai berikut:

1. Unsur Pelaku usaha;

Pengaturan mengenai pendefinisian pelaku usaha dapat ditemukan dalam Pasal 1 angka 5 UU 5/1999 yang menerangkan bahwa yang dimaksud pelaku usaha adalah setiap orang perseorangan atau badan usaha, baik yang berbentuk badan hukum atau bukan badan hukum yang didirikan dan berkedudukan atau melakukan kegiatan dalam wilayah hukum negara RI, baik sendiri maupun bersama-sama melalui perjanjian, menyelenggarakan berbagai kegiatan usaha dalam bidang ekonomi. ${ }^{11}$

2. Unsur pelaku usaha lain atau pihak lainnya;

Yaitu di mana adanya pihak lain yang terlibat dalam hal ini pesaing pelaku usaha dan/atau panitia tender atau bahkan pejabat yang berdasarkan kewenangannya dapat mempengaruhi hasil tender yang sepakat untuk mempengaruhi hasil tender guna kepentingan salah satu pihak, misalnya dengan cara batal mengikuti pengajuan penawaran atau melakukan penawaran hanya sebagai pemenuhan syarat.

${ }^{9}$ Resmaya Agnesia Mutiara Sirait, "Larangan Tindakan Persekongkolan Dalam Tender Berdasarkan Undang-Undang Nomor 5 Tahun 1999 Tentang Larangan Praktik Monopoli Dan Persaingan Usaha Tidak Sehat", Tanjungpura Law Journal,Vol.4, No.2, (Juli 2020): 182.

${ }^{10}$ Resmaya Agnesia Mutiara Sirait, Op.Cit hlm. 182.

${ }^{11}$ Andi Fahmi Lubis, dkk, Hukum Persaingan Usaha Antara Teks \& Konteks (Jakarta: Komisi Pengawas Persaingan Usaha, 2009), hlm 151-152. 


\section{Unsur bersekongkol;}

Dalam prakteknya persekongkolan tender dilakukan oleh dua atau tiga pihak yang di mana para pihak memiliki kepentingan dalam tender tersebut. Yang di mana bentuk persekongkolan tersebut dapat berupa perlakuan tindakan diskiriminatif kepada pelaku usaha lain, membocorkan penawaran pihak lain guna untuk melakukan penyesuaian harga penawaran, melakukan pendaftaran semu agar seolah-olah tender dilakukan dengan terbuka dan kompetitif dan bahkan memberikan perlakuan ekslusif kepada pelaku usaha terntu. Berdasarkan jenisnya persengkongkolan tender dapat diklasifikasikan sebagai berikut: ${ }^{12}$

a. Persekongkolan Horizontal, yaitu persekongkolan yang dilakukan oleh pelaku usaha atau penyedia barang/jasa bersama dengan pelaku usaha dan penyedia jasa lainya atau pesaingnya.

b. Persekongkolan Vertikal, yakni persekongkolan yang dilakukan oleh satu atau lebih pelaku usaha/jasa dengan panitia pelaksana tender, panitia lelang, atau pengguna barang dan jasa atau pemeiliki atau pemberi pekerjaan.

c. Persekongkolan Gabungan, yakni persekongkolan yang dilakukan oleh pelaku usaha atau penyedia barang/jasa bersama dengan pelaku usaha dan penyedia jasa lainya atau pesaingnya serta panitia pelaksana tender, panitia lelang, atau pengguna barang dan jasa atau pemeiliki atau pemberi pekerjaan.

4. Unsur mengatur dan/atau menentukan pemenang tender;

Dalam pedoman mengenai praktik persekongkolan tender yang dimaksud dengan unsur mengatur adalah serangkaian tindakan yang dilakukan oleh para pihak yang terlibat dalam persekongkolan untuk menyingkirkan pelaku usaha pesaing atau mengatur dan menetapkan pelaku usaha pemenang tender dengan berbagai tindakan manipulatif dan/atau tindakan lainnya berupa hal-hal mengenai kriteria pemenang, persyaratan teknik, keuangan, spesifikasi, proses tender dan sebagainya.

5. Unsur dapat mengakibatkan terjadinya persaingan usaha tidak sehat

Persaingan usaha tidak sehat didefinisikan sebagai persaingan yang tidak jujur atau persaingan curang di mana persaingan usaha yang terjadi oleh para pelaku usaha dilakukan dengan cara melawan hukum guna untuk menghambat pesaingnya guna mendapatkan keuntungan dan akses pasar yang sebesar-besarnya.

Persekongkolan tender dilarang karena dapat menimbulkan dampak negatif yakni persaingan usaha tidak sehat, merusak iklim persaingan usaha, menghilangkan nilai kompetitif, merusak kepercayaan publik terhadap proses tender dan bahkan menimbulkan kerugian negara karena didalamnya terdapat kegiatan memanipulasi harga penawaran guna memberikan keuntungan lebih kepada pihak yang bersekongkol. Di mana yang seharusnya pelaku usaha dalam mengikuti penawaran tender dengan tertutup, adil dan kompetitif, malah bersekongkol untuk menaikkan atau menurunkan harga, kualitas barang/jasa untuk para pembeli yang ingin memperoleh barang/jasa melalui suatu proses pengadaan. ${ }^{13}$ Maka berdasarkan dampak negatif yang ditimbulkan tersebut sudah seharusnya penarpan sanksi dalam persekongkolan tender ditegakkan.

Penerapan sanksi dalam praktik persekongkolan tender dilakukan dengan cara mengimplementasikan ketentuan-ketentuan yang terdapat dalam UU 5/1999 hal tersebut berujuan untuk menghapuskan hambatan-hambatan dalam persaingan usaha yang merupakan wujud persaingan usaha tidak sehat. Penjatuhan sanksi dalam konteks persekongkolan tender dapat dikulifikasikan menjadi dua yaitu sanksi administratif dan sanksi pidana.

Ketentuan mengenai sanksi administratif dapat ditemukan dalam Pasal 47 UU 5/1999 yang dalam pengaturannya memberikan kewenangan kepada KPPU untuk menjatuhkan sanksi Administrasi terdahap pihak-pihak yang melakukan persekongkolan tender berupa:

1. Penghentian kegiatan;

2. Penetapan kewajiban ganti rugi;

3. Penjatuhan denda.

Selain sanksi administratif pelaku persekongkolan tender juga dapat dijatuhi hukum pidana, yang ketentuannya terdapat dalam Pasal 48 Ayat (2) dan Ayat (3) UU/5/1999 berupa:

1. Pidana denda paling rendah Rp. 5.000.000.000,00 (lima miliar rupiah) dan paling tinggi Rp. 25.000.000.000,00 (dua puluh lima miliar rupiah), atau pidana pengganti kurungan paling lama 5 (lima) Bulan.

2. Pidana denda paling renda Rp. 1.000.000.000,00 (satu miliar rupiah) dan paling tinggi Rp. 5.000.000.000,00 (lima miliar rupiah), atau pidana pengganti kurungan paling lama 3 (tiga) Bulan. Sanksi ini dijatuh kandalam hal pelaku usaha menolak untuk menyerahkan alat bukti guna untuk proses penyelidikan dan/atau pemeriksaan atau menolak

${ }^{12}$ Hj. Muskibah, SH, M.Hum, ’Larangan Persekongkolan Dalam Tender Persfektif Undang-Undang Nomor 5 Tahun 1999 Tentang Larangan Praktek MonopoliDan Persaingan Usaha Tidak Sehat", Jurnal Ilmu Hukum INOVATIF Vol 6, No.7 (2013): 5868.

\footnotetext{
${ }^{13}$ Asmah, Op.Cithlm 200.
} 
diperiksa, menolak memberikan keterangan yang diperlukan dalam proses penyelidikan dan/atau pemeriksaan, atau menghambat proses penyelidikan dan/atau pemeriksaan sebagai mana dalam Pasal 41 Ayat (1) dan Ayat (2).

Pidana tambahan juga dapat dijatuhkan terhadap para pelaku yang melanggar Pasal 48 sebagai mana ketentuan dalam Pasal 49 UU 5/1999 berupa:

1. Pencabutan Izin Usaha;

2. Larangan untuk menduduki jabatan direksi atau komisaris paling singkat 2 (dua) tahun dan paling lama 5 (lima) tahun;

3. Penghentian kegiatan atau tindakan tertentu yang merugikan pihak lain.

Terhadap kasus persekongkolan tender yang didalamnya melibatkan pegawai atau pejabat pemerintah yang diberikan kewenangan atau berdasarkan jabatannya tersebut memiliki kaitanya dalam kasus persekongkolan tender maka KPPU dapat menyampaikan kasus tersebut kepada penegak hukum terkait.

\section{Pemenuhan Unsur-Unsur Persekongkolan Tender pada Putusan Komisi Pengawas Persaingan Usaha Perkara Nomor 04/KPPU-L/2018}

Praktik persekongkolan dalam tender untuk menentukan pemenang dan menguntungkan para pihak yang bersekongkol tentu akan menciderai pasar persaingan sehingga menimbulkan persaingan usaha yang tidak sehat. Diterapkannya ketentuan persekongkolan dalam Pasal 22 Undang-Undang Nomor 5 Tahun 1999 bergantung pada 2 (dua) komponen penting yakni pertama terdapat para pihak dengan menunjukan keikutsertaan dirinya dalam kesepakatan persekongkolan, kedua telah melakukan kesepakatan untuk melaksanakan kegiatan yang bersesuaian melalui koordinasi antar pelaku usaha dengan pelaku usaha lain maupun pihak lain serta bersifat kolusif. ${ }^{14}$

Penegakan dalam persaingan usaha termasuk persekongkolan tender yang diatur dalam Undang-Undang Nomor 5 Tahun 1999 diwujudkan melalui peranan Komisi Pengawas Persaingan Usaha (KPPU). KPPU ialah sebuah lembaga atau institusi yang bersifat independen sehingga terlepas dari lembaga lain serta didirikan berdasarkan UndangUndang untuk mengawasi jalannya Undang-Undang Nomor 5 Tahun 1999 serta bertanggungjawab secara langsung kepada Presiden. ${ }^{15}$ Dalam melaksanakan tugasnya KPPU juga memiliki kewenangan untuk mengadili dan member putusan pada kasus persaingan usaha termasuk perkara yang berkaitan dengan pelanggaran pada persekongkolan tender.

Dalam kasus persekongkolan tender pada paket lelang preservasi rekonstruksi jalan dan pemeliharaan rutin jembatan Palangka Raya-Bagugus-Bukit Batu dilakukan berbagai cara oleh para Terlapor yang merupakan Panitia penyelenggara tender dan pelaku usaha yang menjadi partisipan tender dalam perkara ini. Hal tersebut dilakukan demi menentukan pelaku usaha yang akan menjadi pemenang dalam tender tersebut. Dalam proses penyelenggaraan tender tersebut terdapat beberapa kejanggalan di antaranya terdapat kesamaan antara dokumen penawaran Terlapor I dengan III, Surat Dukungan Bank yang sama serta berurutan, IP Address yang sama, rentang waktu log in dan log out yang berhimpitan serta kesamaan meta data yang menujukan adanya koordinasi antara para Pelaku Usaha yang ditetapkan sebagai Terlapor dalam perkara tender ini guna melakukan pengaturan untuk menetapkan pemenang dalam tender tersebut. Seharusnya apabila ditemukan kejanggalan atau indikasi bahwa telah terjadi persekongkolan tender yang merupakan praktek persaingan usaha tidak sehat maka panitia penyelenggara tender harus membatalkan proses tender tersebut. Berdasarkan kronologi kasus tersebut tindakan yang telah dilakukan para terlapor telah menjalankan langkah persekongkolan dan melanggar hukum persaingan dalam berusaha.

Sebagaimana ketentuan Pasal 22 Undang-Undang Nomor 5 Tahun 1999 yang telah diubah dalam putusan Mahkamah Konstitusi Nomor: 85/PUU-XIV/2016 bahwa "Pelaku usaha dilarang bersekongkol dengan pelaku usaha lain dan/atau pihak yang terkait dengan pelaku usaha lain untuk mengatur dan/atau menentukan pemenang tender sehingga dapat mengakibatkan terjadinya persaingan usaha tidak sehat."Berdasarkan kasus posisi pada Putusan Komisi Pengawas Persaingan Usaha Nomor 04/KPPU-L/2018 bahwa para terlapor telah melanggarketentuan Pasal 22 Undang-Undang Nomor 5 Tahun 1999 tentang Persekongkolan Tender. Ketentuan pasal 22 terdiri dari beberapa unsur yang jika dijabarkan dan dikaitkan dengan fakta-fakta yang terdapat dalam kasus persekongkolan tender, maka unsur adanya persekongkolan tender akan terpenuhi. Pemenuhan unsur-unsur dalam persekongkolan tender pada Putusan KPPU Nomor 04/KPPU-L/2018 yakni:

\footnotetext{
${ }^{14}$ Dewi Nawang Wulan, Ainul Masruroh, Rusydi, Op. Cit hlm 109-110.
}

15 Surya Bakti, Zainal Asikin, Sahnan, "Eksistensi Komisi Pengawas Persaingan Usaha Dalam Penanganan Persekongkolan Tender Perspektif Hukum Indonesia”, Pagaruyuang Law Journal Vol. 3 No.2, (Januari 2019): 264-265 


\section{Unsur Pelaku Usaha}

Dalam hal ini pelaku usaha yang dimaksud adalah pelaku usaha yang ditentukan sebagai pemenang tender melalui praktik persekongkolan. Unsur pelaku yang dimaksud dalam perkara persekongkolan pada putusan ini adalah Terlapor II yakni PT. Jaya Wijaya Coperation yang merupakan pemenang tender dalam perkara a quo.

PT. Jaya Wijaya Coperation merupakan sebuah badan hukum berbentuk perseroan terbatas yang didirikan di Indonesia berdasarkan perubahan terakhir Akta Perusahaan Nomor 28 Tanggal 14 April 2015. Terlapor II menjalankan kegiatan usahanya di bidang jasa pelaksana konstruksi jalan, jalan raya, kereta api dan landas pacu bandara. PT. Jaya Wijaya Coperation merupakan salah satu peserta tender yang kemudian ditetapkan sebagai pemenang dalam tender pada lelang preservasi rekonstruksi jalan dan pemeliharaan rutin jembatan Palangka RayaBagugus-Bukit Batu, namun hal itu dilakukan dengan adanya persekongkolan antara Pokja, PT. Jaya Wijaya Coperation dan PT. Margo Umega. Bertitik tolak pada hal tersebut, maka unsur pelaku usaha Pasal 22 UndangUndang Nomor 5 Tahun 1999 dalam perkara persekongkolan tender ini telah terpenuhi.

\section{Unsur pelaku usaha lain atau pihak lainnya}

Pelaku usaha lain dalam Perkara a quo adalah Terlapor III yaitu PT. Margo Umega. Bahwa dalam proses persidangan, berdasarkan keterangan dari Terlapor II (PT. Jaya Wijaya Coperation) membenarkan dan bertanggung jawab pada penawaran yang telah diteruskan oleh terlapor III (PT. Margo Umega) dan PT. Melindo Bhakti Persadatama dalam tender melalui pengendalian atas kedua perusahaan peserta tender, hal ini dilakukan demi menjadi pemenang dalam tender pada perkara a quo. PT. Margo Umega ialah pelaku usaha di bidang jasa konstruksi yang didirikan melalui Akta Perusahaan dengan perubahan terakhir Nomor 03 Tanggal 02 Mei 2014. PT. Margo Umega merupakan salah satu peserta tender yang terlibat dalam persekongkolan melalui perannya sebagai perusahaan pendamping. Dokumen penawaran serta pendukung selama mengikuti tender telah disiapkan oleh perusahaan utama yaitu PT. Jaya Wijaya Coperation. Berlandaskan uraian tersebut, maka dengan ini unsur pelaku usaha lain dalam kasus persekongkolan tender telah terpenuhi.

Sedangkan yang dimaksud dengan pihak lain adalah pihak yang terkait dengan pelaku usaha lain, arti dari frasa "pihak lain" ini telah diperluas melalui Putusan Mahkamah Konstitusi Nomor 85/PUU-XIV/2016 tentang pengujian UU Nomor 5 Tahun 1999. Dengan demikian pihak lain dalam tender ini ialah pihak yang berpartisipasi dalam proses persekongkolan dengan melakukan pengaturan serta menentukan pemenang tender sehingga menimbulkan persaingan usaha yang tidak sehat. Para terlapor dalam perkara ini merupakan subjek hukum yang patut diduga telah melakukan pelanggaran terhadap ketentuan Pasal 22 UU Nomor 5 Tahun 1999. Subjek hukum yakni segala sesuatu yang pada hakikatnya sebagai pemangku hak dan kewajiban di bidang hukum, subjek hukum sendiri mencakup orang dan badan hukum. Bahwa berdasarkan hal tersebut maka Kelompok Kerja (Pokja) Pengadaan Barang/Jasa Satuan Kerja Pelaksanaan Jalan Nasional Wilayah III Provinsi Kalimantan Tengah merupakan subjek hukum yang segala perbuatannya harus dipertanggungjawabkan secara hukum. Oleh karena itu, unsur pihak lain dalam persekongkolan tender ini telah dipenuhi.

\section{Unsur bersekongkol}

Para terlapor dalam Putusan KPPU Nomor 04/KPPU-L/2018 dalam melakukan tender telah memenuhi unsur persekongkolan secara horizontal dan vertikal. Persekongkolan horizontal dilakukan dengan adanya kerja sama antar pelaku usaha pada saat menawarkan harga dalam tender, kemudian mereka melakukan kesepakatan untuk memutuskan siapa yang akan ditetapkan untuk menjadi pemenang dalam tender. Persekongkolan horizontal dalam perkara tender ini dapat dilihat dari adanya koordinasi antara Terlapor II dan Terlapor III dalam melaksanakan tender. Terlapor III bertugas sebagai perusahaan pendamping dan meminjamkan perusahaannya kepada Terlapor II dengan mendapatkan keuntungan sebesar $2,5 \%$. Koordinasi yang dilakukan tersebut terlihat dengan adanya kesesuaian $I P$ Address yang dipakai dalam mengakses pada situs Lembaga Pengadaan Secara Elektronik (LPSE) maka hal ini menunjukan bahwa dokumen penawaran diunggah melalui perangkat dengan jaringan yang serupa. Selain itu rentang waktu pada saat memasuki dan keluar dari situs LPSE berdekatan sehingga hal ini mengindikasikan adanya komunikasi antara para terlapor. Kemudian juga terdapat kesamaan metadata pada penyusunan dokumen penawaran tender dengan menggunakan $P D F$ version dab producer yang persis dengan identitas file penawaran yang hampir sama. Penyertaan Surat Keterangan Dukungan Bank (SKBD) pun menunjukan adanya persekongkolan antara Terlapor II dan Terlapor III yang tampak dari nomor seri pada surat yang berurutan sebab dikeluarkan oleh bank yang sama yaitu Bank Kalteng. Berbagai bukti tersebut dikuatkan dengan pengakuan Terlapor II yakni PT. Jaya Wijaya Coperation yang menerangkan bahwa perusahaannya memiliki peran sebagai pemimpin dalam tender ini dan menyusun strategi persekongkolan. Akibat tindakan tersebut membuktikan bahwa terdapat komunikasi untuk melakukan kerja sama antar para Pelaku Usaha yang menjadi Terlapor dalam perkara a quo pada saat melakukan persiapan maupun penyusunan dokumen penawaran juga sebagai upaya pengaturan harga dengan mewujudkan 
persaingan semu sehingga dapat menyebabkan persaingan usaha yang tidak sehat sehingga dapat menghalangi pelaku usaha lain untuk masuk ke dalam pasar dan bersaingan secara kompetitif dalam proyek Tender tersebut.

Di sisi lain, para terlapor juga memenuhi unsur persekongkolan secara vertikal yang dilakukan oleh pelaku usaha yang mengikuti tender dengan panitia lelang. Persekongkolan vertikal dalam perkara persekongkolan tender ini terlihat dari tindakan pojka yang tidak mengeliminasi peserta tender yang bersekongkol walaupun telah ditemukan kesamaan dalam metode pelaksanaan serta SKDB yang berurutan dengan diterbitkan oleh bank yang sama untuk memenuhi persyaratan tender Terlapor II dan Terlapor III. Pada saat menggugurkan PT. Margo Umega pun sebagai Terlapor III nampak bahwa pokja hanya membuat alasan yang tidak didasarkan dengan peraturan yang ada. Dalam proses tender PT. Margo Umega digugurkan dengan alasan tidak mensubkontraktorkan pekerjaan pasangan batu dengan mortar, padahal di dalam Perpres Nomor 54 Tahun 2010 tidak disebutkan bahwa peserta dalam proses lelang wajib mensubkontraktorkan pekerjaannya. Selain itu pengguguran PT. Ganisha Dwi Utama dan PT. Multi Karya Primas Mandiri sebagai peserta lelang pun tidak berdasarkan alasan yang valid. PT. Ganisha Dwi Utama dieliminasi dari lelang sebab tidak mencantumkan jangka waktu pemeliharaan rutin, padahal sebenarnya jangka waktu tersebut telah termuat dalam dokumen. Sementara itu PT. Multi Karya Primas Mandiri digugurkan karena harga penawaran lelang terbilang tidak wajar tanpa disertai dengan pendapat ahli, semestinya panitia tidak memiliki hak untuk menentukan kewajaran atas harga yang ditawarkan peserta lelang. Segala tindakan yang dilakukan pokja atau panitia lelang tersebut semata-mata hanya untuk memenangkan Terlapor III PT. Jaya Wijaya Coperation. Pojka dengan sengaja mengugurkan peserta tender lalu menyandingkan antara peserta lelang dengan rentang harga tinggi yaitu PT. Jaya Wijaya Coperation dan rentang harga penawaran rendah yaitu PT. Multi Karya Primas Mandiri, kemudian menentukan pemenang tender dengan harga yang lebih tinggi. Pada persekongkolan tender ini pokja bertugas memfasilitasi dan mengarahkan Terlapor II untuk memenangkan tender. Berdasarkan hal tersebut maka unsur vertikal dalam perkara persekongkolan tender ini telah dipenuhi.

\section{Unsur mengatur dan/atau menentukan pemenang tender}

Pemenuhan unsur ini nampak jelas melalui adanya keterlibatan Terlapor II dan Terlapor III dalam penyusunan dokumen dalam rangka menentukan pemenang tender. Selain itu, segala bentuk tindakan Terlapor I yaitu pokja ialah untuk mendukung kemenangan yang akan diperoleh PT. Jaya Wijaya Coperation dengan fasilitas berupa strategi pengaturan untuk menentukan pemenang tender. Pokja dalam melaksanakan tugasnya sebagai panitia lelang pun telah lalai dengan tidak mengindahkan segala petunjuk yang mengarahkan adanya persekongkolan antar pelaku usaha dalam hal ini adalah Terlapor II dan Terlapor III. Bahwa setiap kegiatan yang menjadi persekongkolan horizontal dan persekongkolan vertikal oleh para terlapor dalam perkara ini menjadi semakin jelas karena hal itu dilakukan untuk mengatur serta menentukan pemenang dalam tender lelang preservasi rekonstruksi jalan dan pemeliharaan rutin jembatan Palangka Raya-Bagugus-Bukit Batu Kalimantan Tengah. Beralaskan hal tersebut maka unsur mengatur dan/atau menentukan pemenang tender sudah dipenuhi.

\section{Unsur persaingan usaha tidak sehat}

Berdasarkan segala bentuk uraian yang telah dijabarkan pada unsur-unsur sebelumnya menandakan bahwa setiap perbuatan yang dijalankan oleh terlapor merupakan bentuk tindakan tidak jujur sehingga dapat menghambat persaingan usaha yang sehat. Sesungguhnya persekongkolan horizontal untuk memanifestasikan persaingan usaha semu sehingga menafikan persaingan sehat dalam tender yang telah dilakukan Terlapor II dan Terlapor III tidak terpisahkan dari persekongkolan vertikal melalui peran Terlapor I yaitu pokja dalam memberikan fasilitas kelancaran dalam melakukan konspirasi tender. Maka dari itu, tindakan para terlapor ini telah melanggar ketentuan Pasal 22 UU Nomor 5 Tahun 1999 dan menyebabkan persaingan usaha tidak sehat dalam tender serta mencegah pelaku usaha lain untuk masuk ke dalam pasar persaingan tender yang sehat.

Dengan demikian, segala tindakan yang dilakukan oleh para Terlapor dalam perkara a quo telah memenuhi perumusan unsur yang dimaksud dengan persekongkolan tender sebagaimana dimaksud dalam Pasal 22 UndangUndang Nomor 5 Tahun 1999 tentang Larangan Praktek Monopoli Dan Persaingan Usaha Tidak Sehat. Maka artinya, secara sah dan meyakinkan bahwa para Terlapor telah melakukan praktek persekongkolan tender dalam tender a quo. Dalam perkara a quo berdasarkan Putusan Komisi Pengawas Persaingan Usaha Nomor 04/KPPU-L/2018 telah menjatuhkan saknsi terhadap para Terlapor II dan III dalam perkara a quo berupa denda untuk Terlapor II sebesar Rp. 1.709.446.598,00 (satu miliar tujuh ratus Sembilan juta empat ratus empat puluh enam ribu lima ratus Sembilan puluh delapan ribu rupiah) dan denda untuk Terlapor III sebesar Rp. 1.000.000.000,00 (satu miliar rupiah) serta melarang para terlapor untuk ikut serta secara bersama-sama dalam lelang pengadaan barang maupun jasa pada pekerjaan yang sama.

Namun terhadap panitia penyelenggara tender yaitu pegawai atau pejabat pemerintah yang terlibat secara langsung dalam persekongkolan tender Majelis KPPU yang memeriksa perkara a quo tidak dapat menjatuhkan sanksi 
apapun dalam putusannya. Hal itu dikarenakan Undang-Undang Nomor 5 Tahun 1999 tidak memuat aturan mengenai sanksi yang diberikan kepada panitia tender yang telah turut serta dalam perkara persekongkolan sehingga KPPU sebagai lembaga penegak hukum persaingan usaha tidak memiliki wewenang dalam menjatuhkan sanksi terhadapnya. Sudah semestinya ruang lingkup penegakan hukum pada persekongkolan tender untuk panitia lelang menjadi kewenangan penyidik perkara pidana, namun realitanya hal ini belum diatur secara konkrit dalam Undang-Undang Nomor 5 Tahun 1999. Oleh sebab itu, hendaknya KPPU melakukan koordinasi dengan penyidik Kepolisian, Kejaksaan maupun KPK dalam menegakan hukum persaingan di sektor tender untuk mengoptimalkan usaha dalam menciptakan persaingan yang sehat. ${ }^{16}$

\section{SIMPULAN}

Berdasarkan apa yang telah diuraikan dalam pembahasan dapat disimpulkan sebagai berikut:

1. Dalam hukum persaingan usaha praktik persekongkolan tender merupakan tindakan yang dilarang. Larangan tersebut didasarkan pada begitu banyaknya dampak negatif yang ditimbulkan didalamnya yaknimerusak iklim persaingan usaha, menghilangkan nilai kompetitif, merusak kepercayaan publik terhadap proses tender dan bahkan menimbulkan kerugian negara karena didalamnya terdapat kegiatan memanipulasi harga penawaran.Dalam menentukan apakah suatu tender didalamnya terjadi persekongkolan tender maka harus dilihat kembali apakah tender tersebut telah memenuhi unsur-unsur yang terdapat dalan Pasal 22 UU 5/1999. Maka untuk menciptakan iklim usaha yang sehat dan kompetitif sudah seharusnya penarapan sanksi dalam praktik persekongkolan tender ditegakan, baik sanksi administrif ataupunsanksi pidana.

2. Berdasarkan uraian unsur-unsur Pasal 22 UU 5/1999 yang dikaitkan dengan kasus posisi pada Putusan KPPU Nomor 04/KPPU-L/2018 dapat dipastikan bahwa para terlapor sudah memenuhi setiap unsur tersebut, hal ini didukung dengan berbagai bukti yang mengarahkan bahwa adanya indikasi persekongkolan guna memenangkan tender. Berdasarkan hal tersebut para terlapor pun dinyatakan bersalah dengan melakukan persekongolan tender dan menjatuhkan sanksi administratif kepada PT. Jaya Wijaya Coperation dan PT. Margo Umega. Namun hal yang sangat disayangkan adalah Undang-Undang Nomor 5 Tahun 1999 hingga saat ini belum mengatur mengenai sanksi bagi pihak lain yang terlibat dalam persekongkolan sehingga panitia lelang pada perkara ini hanya dinyatakan bersalah atas kelalaian yang dibuatnya saja tanpa diberikan sanksi apapun.

\section{DAFTAR PUSTAKA}

\section{Buku}

Ibrahim , Johnny, Hukum Persaingan Usaha: Filosofi, Teori, dan Implikasi Penerapannya di Indonesia, Malang: : Bayumedia Publishing, 2007

Lubis, Andi Fahmi, dkk, Hukum Persaingan Usaha Antara Teks \& KonteksJakarta: Komisi Pengawas Persaingan Usaha, 2009

Marbun, Rocky, Persekongkolan Tender Barang/Jasa, Yogyakarta: Pustaka Yustisia, 2010

Susanti, dkk, Penelitian Hukum Legal Research, Yogyakarta: Sinar Grafika, 2017

\section{Artikel Jurnal Online}

Asmah, "Penerapan Sanksi Denda Terhadap Kasus Persekongkolan Tender Jalan Nasional" (2019, Agustus), Jurnal Yudisial Vol. 12, No. 2, (Agustus 2019)

Bakti, Surya, Zainal Asikin, Sahnan, "Eksistensi Komisi Pengawas Persaingan Usaha Dalam Penanganan Persekongkolan Tender Perspektif Hukum Indonesia", Pagaruyuang Law Journal Vol. 3 No.2, (Januari 2019)

Hj. Muskibah, SH, M.Hum, "Larangan Persekongkolan Dalam Tender Persfektif Undang-Undang Nomor 5 Tahun 1999 Tentang Larangan Praktek MonopoliDan Persaingan Usaha Tidak Sehat", Jurnal Ilmu Hukum INOVATIF Vol 6, No.7 (2013)

Maheswari, Alya Anindita "Batasan, Wewenang dan Keterlibatan KPPU Dalam Kasus Persekongkolan Tender Menurut Hukum Persaingan Usaha", Jurist-Diction Vol 3, No. 5, (September 2020)

Prabawa, Andryan Dwi, Hadi, Hernawan, "Analisis Kedudukan Hukum Panitia Tender Dalam Kasus Persekongkolan Tender di Indonesia Berdasarkan Undang-Undang Nomor 5 Tahun 1999 Tentang Larangan Praktek Monopoli dan Persaingan Usaha Tidak Sehat", Privat Law Vol. VI, No. 2, (Juli-Desember 2018)

Sirait, Resmaya Agnesia Mutiara, "Larangan Tindakan Persekongkolan Dalam Tender Berdasarkan Undang-Undang Nomor 5 Tahun 1999 Tentang Larangan Praktik Monopoli Dan Persaingan Usaha Tidak Sehat", Tanjungpura Law Journal,Vol.4, No.2, (Juli 2020)

${ }^{16}$ Andryan Dwi Prabawa dan Hernawan Hadi, “Analisis Kedudukan Hukum Panitia Tender Dalam Kasus Persekongkolan Tender di Indonesia Berdasarkan Undang-Undang Nomor 5 Tahun 1999 Tentang Larangan Praktek Monopoli dan Persaingan Usaha Tidak Sehat", Privat Law Vol. VI, No. 2, (Juli-Desember 2018): 171. 
Rendi Ardiansyah dan Margo Hadi Pura, Tinjauan Hukum Persaingan Usaha dalam Praktek Persekongkolan Tender (Studi Putusan Nomor:04/KPPU-L/2018)

Wulan, Dewi Nawang, Ainul Masruroh, Rusydi, "Persekongkolan Tender Dalam Persaingan Usaha Menurut UU NO. 5 Tahun 1999 tentang Larangan Praktik Monopoli dan Persaingan Usaha Tidak Sehat”, Mimbar Yustitia Vol 3 No 3, (Desember 2019)

\section{Peraturan Perundang-Undangan}

Undang-Undang Nomor 5 Tahun 1999 tentang Larangan Praktek Monopoli dan Persaingan Usaha Tidak Sehat

\section{Putusan}

Putusan Komisi Pengawas Persaingan Usaha Nomor 04/KPPU-L/2018 